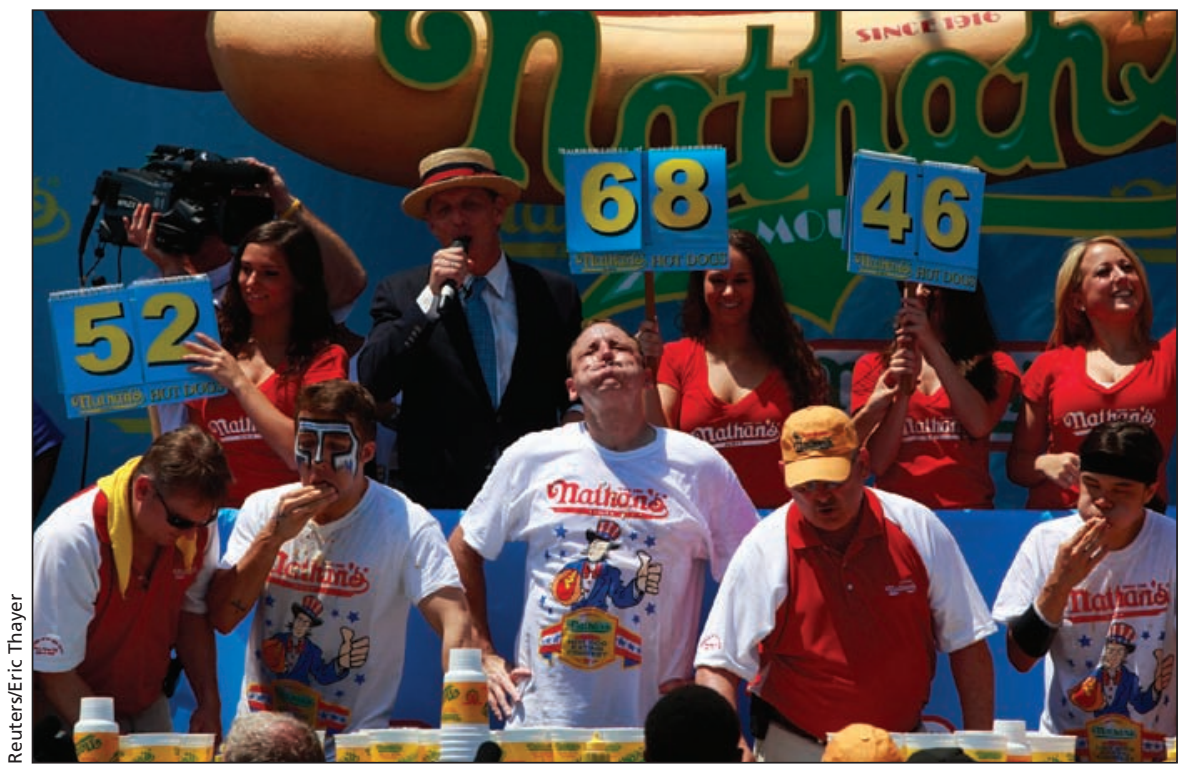

Joey Chestnut (centre) ate 68 hot dogs in 10 minutes to win the 2012 Nathan's Famous Fourth of July International Eating Contest.

the lining of the lower esophagus), Boerhaave syndrome (rupture of esophageal wall) and morbid obesity (due to loss of ability to feel satiated). The repetitive stretching of the stomach may also damage its muscles.

"My concern is if they do this for years and years and years, this long-term chronic overeating may lead to some kind of muscular dysfunction," says Metz.

The risks posed to world-class masticators are likely different than those faced by average individuals who try their hand (and mouth) at speed eating. The stomachs of competitive eaters appear to have unique properties, including the ability to expand by an incredible amount. A typical eater simply could not put away the same amount of food in one sitting.

"In our opinion, average eaters have as much chance of ingesting 50 hot dogs in 12 minutes as executing a triple axel on the ice or running a 4-minute mile," states the study.

One of the greatest risks to average individuals who enter eating contests appears to be choking. In 2002, a 14year-old in Japan choked to death during a competition against friends at his school. In 2004, a 36-year-old man from Canada choked to death after a chicken wing-eating contest in Regina, Saskatchewan. In late 2012, a Florida man choked and died following a bugeating contest.

The professionals who compete in many contests put themselves at risk of becoming obese. Or at least you would think so, considering the amount of calories they consume during an event. The recommended daily caloric intake for the average man is $2000-2500$. A typical hot dog has around 300 calories. So eating 68 at the Nathan's Famous contest works out to more than 20000 calories — in 10 minutes. Then again, perhaps the body doesn't actually use all those calories.

"There are only so many calories you can consume in 10 minutes," says Peter Czerwinski, a professional eater known as Furious Pete. "A lot of stuff goes through undigested."

Like many of the top eaters, Czerwinski remains fit through exercise and controlling calories when not competing. Many competitive eaters fast before and after an event. In fact, being thin allows you to eat more during a contest, according to the "belt of fat" theory, which posits that belly fat restricts the stomach's ability to expand.

The part of competitive eating that may be most risky isn't the competition. "It's a very dangerous thing to train for," says Czerwinski, who is something of a natural and never really took to training to expand his already-pliable belly.

One common technique used to stretch the stomach, for example, is called water loading. It involves chugging one or two gallons of water, which could dilute the electrolytes in the body enough to cause death.

Despite finding a way to stay fit while gorging on high-calorie foods, though, Czerwinski acknowledges that the lifestyles of professional eaters are somewhat crazy. "I think it's stupid for anyone to do, to be frank, though I'm having fun with it," says Czerwinski. "I don't encourage anyone to do it." Roger Collier, CMAJ

CMAJ 2013. DOI:10.1503/cmaj.109-4397

\title{
Limited options for redress
}

$\mathrm{W}$ hen Douglas Fraser's back pain became acute in April 2011, he asked to see a doctor at the Bath Institution, a medium-security federal prison in southern Ontario where he'd been incarcerated for four years. But it was two months before the 58-year-old got his wish, and another four months of searing pain and weight loss, as well as constant demands from family and friends that prison officials escalate his health services, before Fraser was finally taken to Kingston General Hospital for assessment. He was soon diagnosed with pancreatic cancer. In the remaining three months of his life, Fraser contended the delay in providing him access to external care, constituted a death warrant.

Fraser's mother, Muriel, a softspoken native of Tillsonburg, Ontario, is convinced the Correctional Service of Canada (CSC) issued just such a decree. "My son was clearly denied his right to health care equal to what nonprisoners expect."

Dr. Ivan Stewart, the palliative care physician who treated Fraser in the final months of his life, doesn't go quite that far. But Stewart does believe CSC failed to provide equitable health care 
by providing Fraser inadequate palliative care in the Kingston Penitentiary, which is "a totally inadequate facility for a patient to be sent to die in."

Technically, the federal Corrections and Conditional Release Act and various international conventions (www.cmaj .ca/lookup/doi/10.1503/cmaj.109-4407), entitle prisoners to physical and mental health care at a level equivalent in quality to that available outside of prisons. In fact, the act also entitles prisoners to dental care, which is more than is guaranteed the average Canadian, notes Howard Sapers, the Correctional Investigator of Canada.

But if the skyrocketing number of complaints from prisoners about the quality of health care they receive is any indication, the right to health care "is being eroded," Sapers notes. "Access to health care is under duress" and it's only getting worse as prison populations increase and prison health budgets get squeezed. In response, CSC indicated that it is moving to respond to increasing health care demands. To that end, CSC is "implementing a multi-faceted recruitment campaign," says spokeswoman Sara Parkes.

Some argue that the legislative obligations to provide health care extend to preventive medicine, such as harm reduction programs. For example, the Canadian HIV/AIDS Legal Network, based in Toronto, Ontario, has filed a legal challenge under the Canadian Charter of Rights and Freedoms contending that the failure to provide needle exchanges is a breach of a prisoner's right to security of the person and to nondiscriminatory treatment, says Sandra Chu, a lawyer with the network. In refusing to allow needle exchanges, the federal government contravenes its obligation to provide the highest attainable standard of health for a population group in which HIV prevalence is 15 times higher than in the general population, she argues.

Given the legal obligations, what redress exists if a prisoner believes his health rights are being violated? It appears to vary by region.

In British Columbia, the government has funded (through legal aid) a private company to provide legal services to federal and provincial prisoners in the province. About $90 \%$ of complaints are related to health, says Jennifer Met-

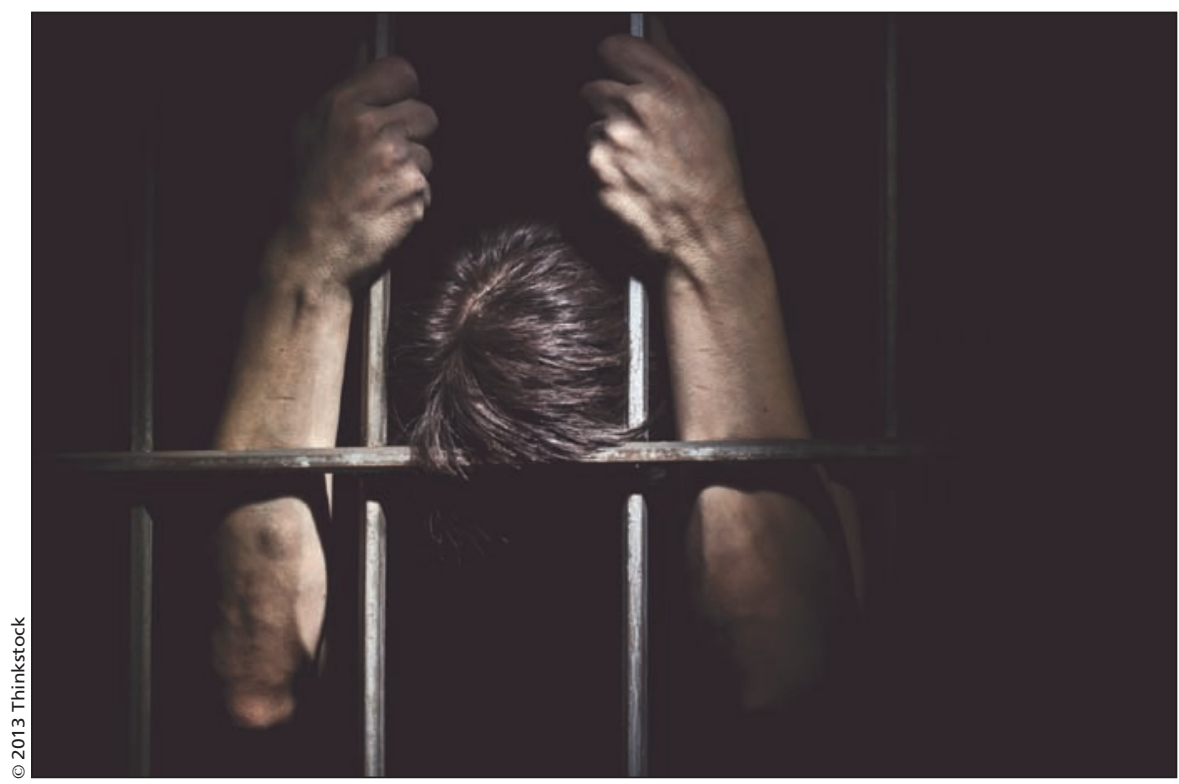

Correctional Investigator of Canada Howard Sapers says that prisoner complaints about health care providers that are forwarded to provincial medical colleges can actually make an inmate's predicament worse. That's because physicians who are under investigation by a college are required to withdraw from treating the complainant.

calfe, a lawyer with the Abbotsfordbased Prisoners' Legal Services. The bulk of such complaints relate to medications, she says, noting that prison medical staff often deny, drug requests due to concerns around security and abuse. Segregation is a common complaint coming from inmates with mental health problems, she adds.

Obtaining action on the complaints is difficult, Metcalfe adds. Complaints about medical decisions are referred to the BC College of Physicians and Surgeons but it hasn't recommended a change in six years, making a remedy through the college an essentially moot point, she notes.

Sapers says that prisoner complaints that are forwarded to provincial medical colleges can actually make an inmate's predicament worse. That's because physicians who are under investigation by a college are required to withdraw from treating the complainant, he says. "In many prisons in Canada there is only one specialist available. So prisoners who complain about their care to the college often further jeopardize getting any care at all."

Provincial medical colleges need to revamp their procedures for handling medical complaints from inmates and establish complaint review panels that include prisoner's legal advocates, argues
Michael Jackson, professor of law at the University of British Columbia.

As for complaints about medical care that is provided by nonphysicians, the procedure appears somewhat convoluted, Metcalfe says. A prisoner can grieve a decision taken by CSC staff, such as a nurse, through the CSC's offender complaints and grievance process. But it's a multistage process, involving two procedures within the prison and then two stages at the regional and national level, that takes at least a year and is encumbered by hurdles that make a prisoner's chances of achieving a medical remedy slim, she argues. "Prisoners with mental health or literacy problems are often even more likely to be exhausted by the process."

The problems are only magnified by the increase in volume of complaints, argues Dave Mullan, emeritus professor of law at Queen's University in Kingston, Ontario.

CSC's four-stage grievance process is overly complex, Mullan says, adding that he urged CSC in a 2010 report to streamline the complaints process.

Moreover, Mullan says that for often illiterate and relatively uneducated prisons, many with mental health problems, it can seem unclear whether they should be pursuing redress through the correctional investigator, through the 
courts or even the Canadian Human Rights Tribunal.

The complexity, for prisoners with health care complaints, is "difficult to fathom," Mullan adds.

Yet even an improved process won't resolve the problem if the system doesn't provide financial support for prisoners in the form of coverage of legal-aid costs, Jackson says. "Typically legal aid is not available to Canadian prisoners with respect to their health care rights. Access to health care services poses a particular legal problem, and it is getting worse due to budget cuts, the increasing number of inmates, and the increasing number of inmates with mental health problems." Paul Christopher Webster, Toronto, Ont.
Editor's note: Sixth of a multipart series on health in the hoosegow.

Part I: Health and hard time (www.cmaj.ca/lookup/doi/10.1503 /cmaj.109-4389).

Part II: Imprisoning the mentally ill (www.cmaj.ca/lookup/doi/10.1503 /cmaj.109-4390).

Part III: Agony behind bars (www.cmaj.ca/lookup/doi/10.1503 /cmaj.109-4391).

Part IV: Black eyes and barriers (www.cmaj.ca/lookup/doi/10.1503 /cmaj.109-4392).

Part V: Providing principled health care in prison (www.cmaj.ca/lookup /doi/10.1503/cmaj.109-4406).

\section{More news online}

Myanmar health services emerging from decades of neglect: Recent reforms in Myanmar suggest that the health sector may be about to get a facelift after a half century of massive underfunding (www.cmaj.ca /lookup/doi/10.1503/cmaj.109-4361). - Steve Finch, Yangon, Myanmar, with additional reporting by Swe Win, Sittwe, Myanmar

Health challenges in the Golden Land: After five decades of military rule, Myanmar is beset by an array of health challenges, including high rates of beri-beri, malaria, HIVIAIDS and tuberculosis (www.cmaj.ca /lookup/doi/10.1503/cmaj.109-4368). — Steve Finch, Yangon, Myanmar

Cultural and societal obstacles in responding to Swaziland's HIV epidemic: The HIV epidemic in the Kingdom of Swaziland has stabilized in the past five years, but the country still has the highest HIV prevalence in the world (www.cmaj.ca/lookup/doi/10.1503/cmaj.109-4396). — Barbara Sibbald, CMAJ

Beyond BlackBerry thumb: Ergonomic experts predict a new generation of hand injuries as a result of the trend toward touch screen versions of smartphones, tablets and other technologies that involve one-finger typing and swiping of the thumb (www.cmaj.ca/lookup/doi/10.1503/cmaj.109-4395). Bonnie O'Sullivan, Ottawa, Ont.

Providing principled health care in prison: Having deprived prisoners of their freedom and the ability to access their own health care, society has an obligation to provide them basic health necessities. What exactly those are, and how and whether they are provided, is another issue altogether (www.cmaj.ca/lookup/doi/10.1503/cmaj.109-4406). — Adam Miller, CMAJ

CMAJ 2013. DOI:10.1503/cmaj.109-4411 